\title{
"CLASS21" - A RESEARCH PROJECT ON INFORMATION TECHNOLOGIES IN THE PEDAGOGICAL PROCESS (2000-2004)
}

\section{Summary}

\section{Introduction}

Class 21 was launched in 2000 as a project of the Education Highway, the Secondary School of the Pädagogische Hochschule der Diözese Linz and the Ministry of Education. Aim of the project was to develop theoretical and didactical principles for learning in a digital environment. It was to last all four years of lower secondary education of the students engaged. Prof. Dr. Eder F., Salzburg, was the scientific monitor and evaluator of the project. During the four year period he compared the development of learning efficiency, self-development and the social climate in Class 21 with a control group of students taught by the same teachers.

\section{Aim of the Study}

To find out how the intensive use of ICT in class affects the classroom climate and the intellectual performance of students.

\section{Materials and methods}

The methods were: Linzer Questionnaire of School and Classroom Climate, MATKOMP I, NATKOMP I and Salzburg Reading Screening (SLS 5-8).

\section{Results and conclusions}

During the project we learned that a focus on social learning and on establishing a good climate of work at school had more effect on the cognitive performance and on the improving of the social climate in class than any modern equipment.

The study showed that ICT may make things easier but has no positive effect on the development in the categories mentioned above.

Key words: Class 21, ICT, development.

\section{Introduction}

"If you want to do your child something good don't buy him/her a computer! ... TV and PC make children fat, stupid and violent." (Spitzer, 2006). Neurobiologist Spitzer's warning came too late, the Austrian Ministry of Education bought notebooks for the project "Class21" of the Adalbert Stifter Teacher's Training School of the Private Pädagogische Hochschule of the Diözese Linz and the Education Highway Upper Austria in 2000.

Aim of the project was to develop theoretical and didactical principles for learning in a digital environment. The project should last the complete four years of lower secondary education of the students engaged.

The Adalbert Stifter Training School provided a group of highly skilled and motivated teachers to teach one group of students $(\mathrm{N}=24)$ in a digital environment (notebooks, whiteboard, video cameras, digital cameras, internet access, e-Learning platforms, learning and teaching software, ...). They wanted to show:

- ICT helps the students to benefit in the cognitive process from "Bloom low" (remember, understand, apply) to "Bloom high" (analyse, evaluate, create) (Bloom, 1976), 
- humanistic ideas and a holistic education do not contradict the use of ICT,

- ICT helps teachers and students to get information, to work with it during the lesson and to present results to the other students,

- new technologies require new teaching methods,

\section{Aim of Study}

To find out how the intensive use of ICT in class affects the classroom climate and the intellectual performance.

\section{Materials and methods}

The teachers involved in the project also taught another group of students $(\mathrm{N}=24)$ in the traditional and proven successful way of the Training School. There were some teachers who feared the extensive working with computers would have negative effects on social matters. That is why a weekly extra lesson of "social learning" was integrated in the schedule of Class 21.

The participation of students in the project was voluntary. Parents, students and teachers split the 48 students which had been admitted to the private school into two groups. This proved to be a rather difficult matter because the students preferred Class 21 whereas quite a number of parents wanted their children taught in the traditional ways of the Training School.

The two groups consisted of 24 students each. A pre-test on cognitive performance should help to split them in two equal groups with a greater number of students with good cognitive and a smaller number of students with not so good cognitive performance. They should match an average Austrian school class of lower secondary level. This should make it possible to compare the cognitive development of the students in the two groups.

The teachers of Class 21 were convinced that on the one hand "nobody learns vocabulary just from pressing keys. The process of learning will always remain an exertive action which requires motivation and commitment. Computers were highly overestimated just like the video recorder or the overhead projector once had been. ... Nevertheless almost nobody would give his PC for an old typewriter." (Nausner, 2003).

Teachers, parents and students of the Adalbert Stifter Training School set value on working independently and on one's own initiative. That meant for students of Class 21 they had to administer their network and their internet servers all alone. They were responsible that access to the internet was available at any time and that data could be transferred to and from every computer at any time. They were also responsible for their personal notebooks $(1.2 \mathrm{~kg})$. So they had to set them up on their own, take them home for homeworks and to reload the batteries before going on excursions or outdoor lessons (Leeb, Knierzinger, 1999).

Prof. Dr. Eder Ferdinand of the University of Salzburg was asked to monitor and evaluate the project. As far as it is known there has not been a comparable study with control groups in the ICT teaching sector.

The presented study is only part of a series of studies made on the project Class 21 and because of its large scale it cannot be presented in detail.

Pedagogical innovations are in general accompanied by hopes and fears. One of the fears was that the intensive use of ICT in class would make it difficult to achieve the goals of the curricula. The process of gaining information could take too much time and the deep look into a subject would get lost. Another fear was that social disputes might influence the students in a negative way.

The hopes focused on the belief that increased use of ICT in class would make the process of learning more autonomous, motivating and efficient. Another hope was that the dynamic 
competences in students would develop in a positive way.

According to the fears and hopes we had to expect that the students of Class 21 would develop better in cognitive performance and in their personal concept. But in the field of social relationships we had to expect development in a more problematic way.

Both groups of students were used to working as teams on projects. But would the ICTresearch tools, ICT-publishing tools and ICT-presenting tools lead to a higher level of motivation and eventually a better mathematical performance, higher level of knowledge in science and a better reading performance? And would the social climate be more problematic in Class 21 than in the control group?

There are more than 60 schools in Austria with about 3,000 students which have established so called "notebook classrooms" - most of them in upper secondary level. Many of them are monitored by the Ministry of Education, but there are no control groups involved. The most common way of evaluation in those groups is to simply ask the students what they think about their instructions and classes. $45 \%$ are of the opinion that the way of teaching in their classes has improved. Therefore everybody involved believes ICT has a positive effect of teaching and learning. But is it that simple?

The study by Dr. Eder should be different. It was an evaluation of a pedagogical innovation on scientific terms. In the process of evaluation social scientific methods were systematically applied on the design, the implementation and the results of the interventions.

The study had basically the classical experimental design of Solomon (1949) with a pre-test in November 2000, three surveys in June 2001, June 2002 and June 2003 and a post-test in June 2004. The test and surveys were conducted in Class 21 and the control group (see Table 1). That made the study unique. As far as I know there are no published studies with control groups, and with the same teachers in both groups in the same school. We tried to keep the differences of the conditions in both groups as little as possible.

Table 1. Timeline of study.

\begin{tabular}{|l|l|l|}
\hline Timeline & $\begin{array}{l}\text { Class21 } \\
\text { Control Group }\end{array}$ & Issues \\
\hline November 2000 & Pretest & $\begin{array}{l}\text { Cognitive performance test and a survey on the attitude to school } \\
\text { and on the climate in class }\end{array}$ \\
\hline June 2001 & First intermediate survey & Personal feeling and climate in class as well as work habits \\
\hline June 2002 & Second intermediate survey & Personal feeling and climate in class as well as work habits \\
\hline June 2003 & Third intermediate survey & Personal feeling and climate in class as well as work habits \\
\hline June 2004 & Posttest & $\begin{array}{l}\text { Cognitive performance test, cognitive development and a survey } \\
\text { on personal feeling and climate in class as well as work habits }\end{array}$ \\
\hline
\end{tabular}

As mentioned above the participation of students was voluntary. The Adalbert Stifter Training School is a private school in which you can find a representative social cross section of the Austrian population. Its students correspond in many aspects with those of a comprehensive school. In each group there were 24 students (14 male/10 female).

Two months after the beginning of the first school year a cognitive performance pre-test was conducted. The instrument used was the "Cognitive Performance Test (KFT 4-12)" of Heller and Perleth (Heller, Perleth, 2000). The test covers linguistic, mathematic and figurative-spatial cognitions, consisting of three sub-test in each category (see Table 2). 
Table 2. Table of subtest categories and characteristic.

\begin{tabular}{|c|c|c|}
\hline Category & & Characteristic \\
\hline Linguistic performance & $\begin{array}{l}\text { L1 vocabulary } \\
\text { L2 verbal classifications } \\
\text { L3 verbal analogies }\end{array}$ & Verbal and logical performance \\
\hline Mathematical performance & $\begin{array}{l}\text { M1 matching quantities } \\
\text { M2 numerical series } \\
\text { M3 forming equations }\end{array}$ & Numerical and logical performance \\
\hline Figurative-spatial performance & $\begin{array}{l}\text { F1 figurative classification } \\
\text { F2 figurative analogies } \\
\text { F3 folding exercises }\end{array}$ & $\begin{array}{l}\text { Logical-inductive performance and } \\
\text { spatial imagination }\end{array}$ \\
\hline
\end{tabular}

The pre-test also contained a questionnaire on the social climate in the two groups. The instrument was "Linzer Questionnaire of School and Classroom Climate" (Eder, Mayr, 2000). The first part of the questionnaire has 42 items which describe 14 aspects of the climate in classroom. They describe four dimensions: peer-group pressure and the pressure to perform, student-cantered education, learning community, rivalry and perturbation. The second part consists of 17 items which cover the feelings and well-being of the children at school. They describe the dimensions of social warmth and strictness/control. There are two more questions about school friends and their school contentment. As the questionnaire was conducted every year it represents a long-time study on the climate in both groups.

At the end of the study the mathematical performance, knowledge in science and reading performance was checked in a post-test again with the "Cognitive Performance Test (KFT 4-12)". In addition MATKOMP I (Eder, Gaisbauer, 2002), NATKOMP I (Eder, Gaisbauer, 2003) - each containing 44 samples of the international TIMSS-Study 1994 - and the Salzburg Reading Screening (SLS 5-8) (Auer, 2005) were conducted.

\section{Results}

In the pre-test (KFT 4-12) both groups of students showed values above average ( $\mathrm{M}=50)$ of Austrian lower secondary school level (see Figure 1). Only in the subcategory M3=forming equations Class 21 was below the Austrian lower secondary school level. In spite of that Class 21 showed better performance than the control group in six of nine subcategories. Although the students had been tested eleven months earlier (before they were admitted to school) Class21 had better intellectual resources in the beginning of the study.

The tests concerning the classroom climate over the period of four years $(\mathrm{t} 0, \mathrm{t} 1, \mathrm{t} 2, \mathrm{t} 3, \mathrm{t} 4)$ also showed better results in Class 21 in all categories. There were some hopes that the better values at the beginning of the study in Class21 would lead to better developments in Class21 than in the control group. Diagram 2 shows the aggregate values of classroom climate of both groups and their extremely positive development during the course of the project (see Figure 2).

The gap between Class 21 and the control group increased during the first and second year of the study. This was due to increasing differences in the subcategories social pressure and the pressure to perform. The differences

Figure 1. KFT-Performance ( $T$-values, median $=50)$.

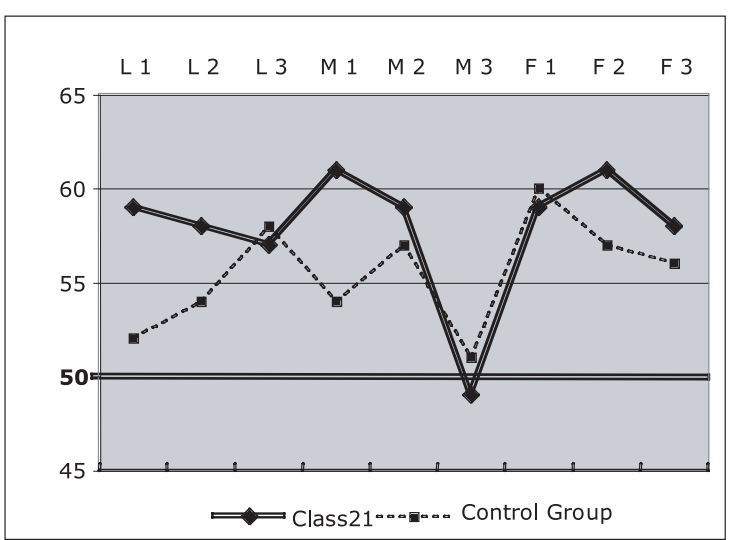


were alarmingly high. In Class21 the values were about 87.9 and in the control group as high as 102.5 which was well above the average of the Austrian lower secondary school level (M=100). During the second year "social learning" was added to the schedule of the control group. Due to that until the end of the study both values were high above average and the gap was not even as wide as at the beginning.

The post-test showed less differences between the two groups but also better values in the tested categories in both classes (Figure 3). The difference in the subcategory $\mathrm{M} 1=$ matching quantities had disappeared and the gap in M3=forming equations had also vanished. Although Class 21 showed slightly better values, they were not statistically significant. The general level (all categories) was well above the average of Austrian lower secondary school level. The difference to the average level had become even higher than in the pre-test.

The TIMSS results (Figure 4) were also above the average level of Austrian lower secondary schools

\section{MATHKOMP I $(\mathrm{M}=63 \%)$}

NATKOMP I (M=64\%)

but the reading screening showed results slightly below average

$(M=100$, standard deviation $=15)$.

Both studies showed a positive development in the two groups of students. The differences which were found at the beginning of the project were still there at the end of the study.

\section{Conclusions}

The intensive use of ICT as tools did not result in statistically significant different values in the fields of cognitive performance nor in classroom climate. Although in Class21 many new skills were developed (editing photographs, working and running wireless networks, administering a net server, programming, setting up computers, ...) no significant effects in basic cognitive performance could be detected. On the other hand we must admit that although there were so many additional focuses and demands (the ECDL had to be obtained by all students of Class 21 , working with new
Figure 2. Aggregate Values of Classroom Climate during the period of four years $(t 0, t 1, t 2, t 4)($ median $=100)$.

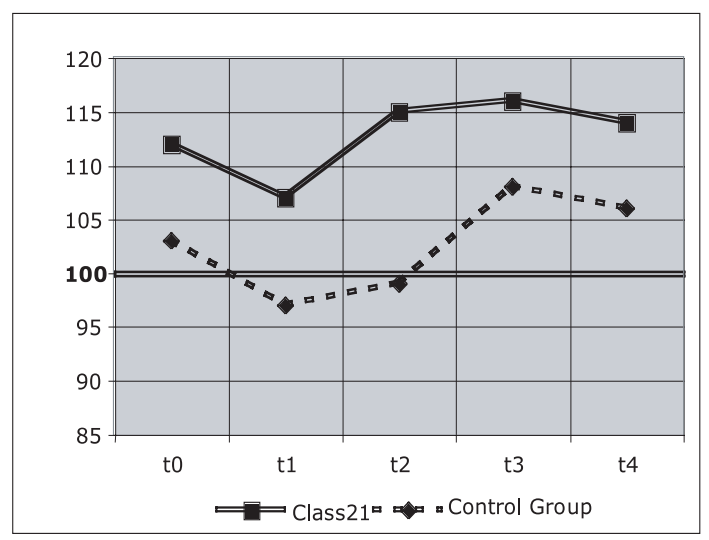

Figure 3. KFT-Performance End of Study (T-values, median $=50)$.

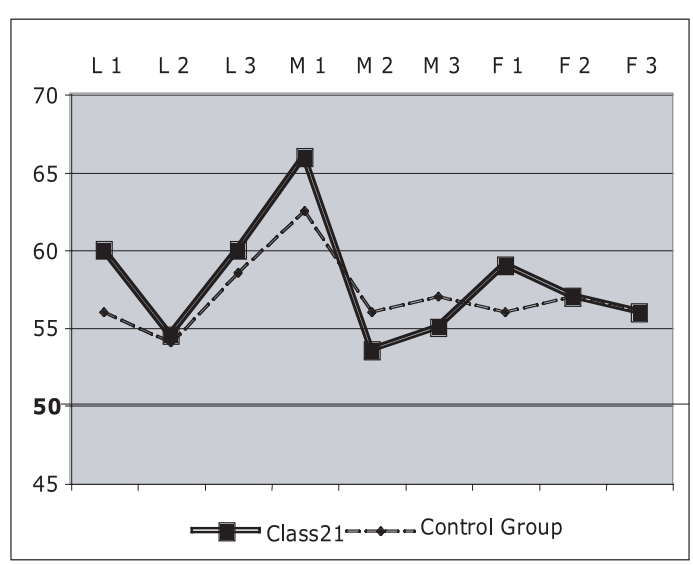

Figure 4. Performance at the end of study in TIMSS (MATHKOMP I \& NATKOMP I) and in Salzburg Reading Screening (SLS).

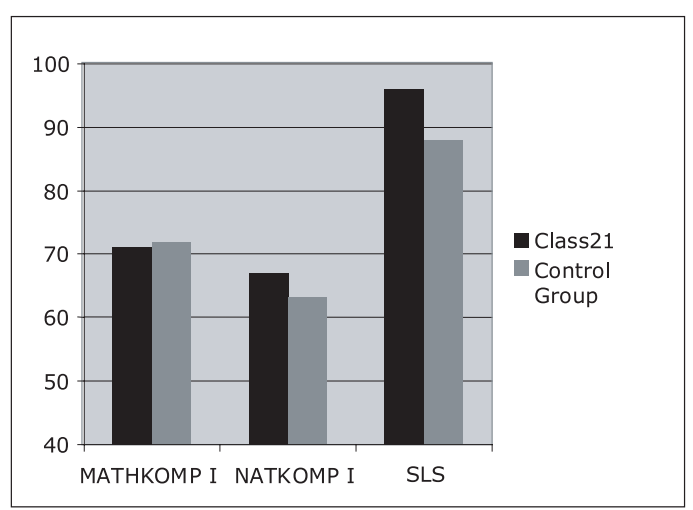


media in classroom had to be presented at the Interpädagogika to teachers and government officials, ...), and that for example no books had been adopted to the needs in such a class, ... Class21 still showed better results than the control group and much better values than an average Austrian lower secondary level class would.

The results also showed that it was important to establish a control group. Otherwise the good values might have suggested that pedagogically highly qualified use of ICT in class resulted in better cognitive performances - especially if you consider that the gap to the average class in Austria had been increasing constantly. Many of the late studies have tried to prove the positive effects of using ICT in classrooms but they have failed because no control groups were installed to show the differences in the results.

Project showed that using ICT in class does not contradict the humanistic ideals and a holistic education. And ICT can make it a lot easier to gain information, to work on the information and to present the results to other persons. The intensive use of ICT made us change our mind in the importance of introducing new teaching methods (Nausner, 2003). On the contrary well approved methods were also effective with modern facilities. They were easy to combine with the use of ICT.

During the project authors learned that a focus on social learning and on establishing a good climate of work at school had more effect on the cognitive performance and on the improving of the social climate in class than any modern equipment.

\section{REFERENCES}

1. Auer M. (2005) Salzburger Lese-Screening für die Klassenstufen 5-8. Bern.

2. Bloom B. S. (1976) Taxonomie von Lernzielen im kognitiven Bereich. Weinheim: Beltz, S. 31.

3. Eder F., Gaisbauer H., Eder C. (2002) MATKOMP I - Ein Verfahren zur Erfassung mathematischer Kompetenzen am Ende der Sekundarstufe I. Erstellt auf Basis von TIMSS-Aufgaben. Rohbericht und Testmanual. Linz: Institut für Pädagogik und Psychologie.

4. Eder F., Gaisbauer H., Eder. (2003) NATKOMPI-Ein Verfahren zur Erfassung naturwissenschaftlicher Kompetenzen am Ende der Sekundarstufe I. Erstellt auf Basis von TIMSS-Aufgaben. Rohbericht und Testmanual. Linz: Institut für Pädagogik und Psychology.

5. Eder F., Mayr J. (2000) Linzer Fragebogen zum Schul-und Klassenklima für die 4.-8. Schulstufe (LFSK 4-8). Göttingen: Hogrefe Verlag.

6. Heller K. A., Perleth C. (2000) KFT. Kognitiver Fähigkeitstest für 4. bis 12. Klassen. Revision. Manual. Göttigen: Beltz Test.

7. Knierzinger A., Leeb A. (1999) CLASS 21 - Klassenzimmer des 21. Jahrhunderts. Projektvorschlag. Linz: IST - Institut für Schule und neue Technologie, S. 1-9.

8. Nausner E. et alt. (2003) Neue Medien - alte Pädagogik? In: Pädaktuell - Fachzeitschrift der Pädagogischen Akademie der Diözese Linz. Linz: PADL Linz. S. 15-24.

9. Spitzer M. (Januar, 2006) TV und PC machen Kinder dick, dumm und gewalttätig. Psychologie Heute. Weinheim: Beltz, $34 \mathrm{~S}$.

\section{Prof. Nausner Ernst}

Private Pädagogische Hochschule der Diözese Linz

Address: Hanuschstraße 12, 4020 Linz, Austria

Phone: +430 6506656751

Fax: +430732797306

E-mail: nae@ph-linz.at 